Available online at GSC Online Press Directory

GSC Biological and Pharmaceutical Sciences

e-ISSN: 2581-3250, CODEN (USA): GBPSC2

Journal homepage: https://www.gsconlinepress.com/journals/gscbps

(RESEARCH ARTICLE)

\title{
Synthesis and characterization of traditionally sourced food spice
}

\author{
Bode Thomas Ifesan, Ayodele Oluwayemisi Ogunlade, Olukayode Adediran Okunade * and Kunle Adesina \\ Department of Food Science and Technology, Federal Polytechnic Ado Ekiti, Ekiti State, Nigeria.
}

Publication history: Received on 20 August 2020; revised on 09 September 2020; accepted on 12 September 2020

Article DOI: https://doi.org/10.30574/gscbps.2020.12.3.0271

\begin{abstract}
Food spices are used globally for diverse culinary and ethno medicinal applications. Therefore the objective of this study was to synthesize food spice from locally available plants (Lippia multiflora leaves, O. gratissimum leaves, ginger (Zingiber officinale) and black pepper (Piper nigrum) seeds), and evaluate its proximate composition, mineral elements, anti-nutritional characteristics, microbial properties, some functional properties and sensory evaluation using trained panelists. The percentage proximate composition revealed that the spice had moisture content of 14.18; protein 11.14; ash 4.31; crude fibre 3.18; fat 19.17 and carbohydrate $48.02 \%$ respectively. The spice had considerable amounts of phosphorus (139.18 ppm), potassium (317 ppm), calcium (63.15 ppm) and vitamin C (38.8 ppm), while zinc and copper were low. The respective phytate, oxalate and tannin values for the food spice was; $8.17 \mathrm{mg} / 100 \mathrm{~g}, 0.03 \mathrm{mg} / 100 \mathrm{~g}$ and $3.64 \mathrm{mg} / 100 \mathrm{~g}$ respectively The sample was analyzed for $\mathrm{pH}$ (6.17), titratable acidity (1.37), solubility (6.14), water absorption capacity (3.1) and swelling power (18.17) respectively. The total viable count for the spice was considerably low $(3 \mathrm{cfu} / \mathrm{ml})$, while coliform bacteria was not detected in the sample. 10 trained panelists assessed the spice and rated its overall acceptability as high. These results indicate that the spice has good physicochemical attributes and contains appreciable amount of food nutrients which can find suitable application in nutrition, food fortification and formulation, and processing.
\end{abstract}

Keywords: Plants; Nutrients; Flavor; Digestion; Health.

\section{Introduction}

Spices constitute an important group of agricultural commodities, which are virtually indispensable in the culinary art. A spice is a dried fruit, seed, root, bark or vegetative substances primarily used for flavouring, colouring or preserving foods. Sometimes a spice is used to hide other flavours. Spices can also be a sort of substances (e.g ginger, nutmeg, cinnamon, cloves etc) used to flavour foods, and can be termed as condiments [1].

The universal use of spices is to flavour foods, this implies its attributes to impact, as well as improve unappetizing and unpalatable foods. Though such foods may be attractive to look at or balanced nutritionally, the essential reflexes required and digestive processes may not be activated without good aroma and taste. The properties and characteristics of spices have been summarized as the ability to give flavour to a flavour-less base, so as to impart a different character to the basic product and boost intrinsic flavours, which, would otherwise be too weak and disguise objectionable intrinsic flavour [2]. Spices are distinguished from herbs which are part of leafy green plants and also used for flavouring or as garnish.

A spice may have an extra use, usually medicinal, religion ritual, cosmetics or perfume production or as a vegetable. For example, turmeric roots are consumed as a vegetable and garlic as an antibiotic $[3,4]$. Many spices have antimicrobial

\footnotetext{
${ }^{*}$ Corresponding author: Olukayode Adediran Okunade

Department of Food Science and Technology, Federal Polytechnic Ado Ekiti, Ekiti State, Nigeria.

Copyright (C) 2020 Author(s) retain the copyright of this article. This article is published under the terms of the Creative Commons Attribution Liscense 4.0.
} 
properties. This may explain why spices are more commonly used in warmer climate, which have more infectious diseases and why the use of spices is especially prominent in meat processing (which is susceptible to spoiling).

From the approximately 300,000 plant species of the planet, more than 200,000 are in the Tropical countries of Africa and have medicinal virtues. In Benin, Akoègninou et al. [4] reported the existence of 2,807 plant species among the local leafy vegetables such as Amarant and Lippia multiflora. Leafy vegetables are plants of which the leaves (including buds and flowers) are used and consumed by the local populations.

Lippia multiflora is an aromatic plant, a shrub of the Verbenaceae family of which inflorescences, leaves and roots are used for food or medicine in Benin Republic, and endowed with a lot of medicinal virtues $[4,5,6]$. Across Africa, the plant is traditionally used to treat bronchial infections, malaria, conjunctivitis, gastric unrests, enteritis and cough $[3,4$, 7]. It also possesses some anti- hypertensive, relaxing, diuretic and antibiotic properties [7, 8]. In Cote d'Ivoire, the plant is used to treat diarrhoea.

Ginger (Zingiber officinale) is a flowering plant whose rhizome, ginger root or ginger, is widely used as a spice and a folk medicine. It is a herbaceous perennial which grows annual pseudo stems, the inflorescences bear pale yellow with purple flowers and arise directly from the rhizome on separate shoots. Ginger is in the family Zingiberaceae. The rhizomes and the leaves were used to flavor food or eaten directly [9].

Black pepper (Piper nigrum) is a flowering vine in the family Piperaceae, cultivated for its fruit, known as a peppercorn, usually dried and used as a spice and seasoning. Peppercorns and the ground pepper derived from them may be described simply as pepper, or more precisely as black pepper (cooked and dried unripe fruit), green pepper (dried unripe fruit), or white pepper (ripe fruit seeds). Ground dried and cooked peppercorns have been used for ages, both for flavour and as a traditional medicine. Black pepper is the world's most traded spice, and is one of the most common spices added to cuisines around the world. Its spiciness is due to the chemical compound piperine, which is a different kind of spice. It is ubiquitous in the modern world as a seasoning, and is often paired with salt and available on dining tables in shakers or mills [10].

Comprehensive biological activities of Ocimum gratissimum has been reviewed and it is associated with antibacterial, antifungal, hypoglycaemic, antipyretic, anti- nociceptive, antioxidant, anti-inflammatory, anthelmintic, chemopreventive, anti-carcinogenic, free radical scavenging, radio protective, anti-dermatophytic activities, and numerous other pharmacological uses [11].

However, when used in larger quantity, spices can also contribute a substantial amount of minerals and other micronutrients, including magnesium, calcium and many others to the diet. Some flavor elements in spices are soluble in water; many are soluble in oil or fat. As a general rule, the flavors from a spice takes time to infuse into the food, so spices are added early in preparation. This contrasts to herbs which are usually added late in preparation. Hence, this study aims to synthesize spice from locally abundant edible plants, characterize its components and compare the synthesized product with established spices from the market.

\section{Material and methods}

\subsection{Sample sourcing}

Matured, blemish free, freshly harvested, leaves of Lippia multiflora and 0. gratissimum; rhizomes of ginger (Zingiber officinale) and black pepper (Piper nigrum) seeds were procured from local farms, near Ekiti State ADP farms, close to Aba Erinfun, Ikare Road, Ado Ekiti, Ekiti State, Nigeria. All these plants were identified by certified botanists at the Department of Botany (Herbarium unit), Ekiti State University, Ado Ekiti, Nigeria.

\subsection{Sample preparation, chemical and sensory assessment}

The leaves of L. multiflora and 0. gratissimum were sorted to remove extraneous matter, while the ginger rhizomes and the black pepper seeds was cleaned thoroughly. The sorted leaves, ginger corms and black pepper seeds were oven dried $\left(40{ }^{\circ} \mathrm{C}\right)$ for four days, milled, and sieved (Fine mesh sized sieves), then packaged individually in air tight labelled containers.

The spice was then prepared from these plant raw materials using the following proportion: 
$40 \mathrm{~g}$ of L. multiflora

$30 \mathrm{~g}$ of 0. gratissimum

$20 \mathrm{~g}$ of ginger

$10 \mathrm{~g}$ of black pepper

The mix was thoroughly homogenized in a clean sterilized baking pan, and packaged in air tight plastic containers and low density polyethylene bags for further evaluation.

All parameters were evaluated in triplicates and the mean of each determination was chosen as the representative value.

Proximate composition of the processed spice was carried out as described by AOAC [12] and modified by Ani et al. [13]. Briefly, the moisture content was determined by difference in weight after drying a weighed portion of the spice at 105 ${ }^{\circ} \mathrm{C}$ until attainment of constant weight. The ash content was evaluated after incinerating a known weight of the sample at $550^{\circ} \mathrm{C}$. The micro kjedahl method of back titration was used to evaluate the protein content using the appropriate $\mathrm{N}$ factor, while fat content was done using continuous soxhlet solvent extraction. The carbohydrate content was determined by difference.

For mineral components evaluation, about $1 \mathrm{~g}$ of the samples was separately weighed to conical flasks followed by addition of aqua regia ( $\mathrm{HNO}, \mathrm{HCl}, 1: 3$ ). The conical flasks were placed in the fume cupboard and heated on a hot plate, at $60^{\circ} \mathrm{C}$ until the material dissolved. The samples were filtered using a filter paper, the filtrate was transferred into 100 $\mathrm{ml}$ volumetric flask and made to mark with distilled water. The diluted sample was used for metals determination using atomic absorption spectrophotometer (Buck $210 \mathrm{vGP}$ ). For each mineral assessed, the corresponding cathode lamps was used (i.e. for iron, iron cathode lamp was used etc) [12,13].

The $\mathrm{pH}$ of the sample was determined using the method described by AOAC [12]. $3 \mathrm{~g}$ of each sample was stirred and allowed to stand for 30 minutes. The $\mathrm{pH}$ was then determined using standardized $\mathrm{pH}$ meter.

Total acidity was assayed by agitating $10 \%(\mathrm{w} / \mathrm{v})$ aqueous suspension of the sample at ambient temperature for 20 minutes and then centrifuging at $1500 \mathrm{rpm}$ for 15 minutes. $25 \mathrm{ml}$ of the supernatant was titrated with $0.1 \mathrm{M} \mathrm{NaOH}$ in the presence of $1 \%$ phenolphthalein solution to a faint persistent pink colour [12].

The methods described by Oladele and Aina [14] were used to evaluate the swelling power and solubility of the synthesized spice. $1 \mathrm{~g}$ of the sample was mixed with $10 \mathrm{ml}$ distilled water in a centrifuge tube and heated at $80{ }^{\circ} \mathrm{C}$ for 30 minutes while shaking continuously. The tube was removed from the bath, wiped dry, cooled to room temperature and centrifuged for 15 minutes at $2200 \mathrm{rpm}$. The supernatant was evaporated, and the dried residue weighed to determine the solubility. The swollen paste obtained from decanting the supernatant was also weighed to determine the swelling power.

For the determination of Oxalates, phytates and tannins, the methods described by Harbonne [15], Pearson [16] and AOAC [12] were used respectively.

Total plate count and coliform bacteria count was evaluated as described by Adegoke [17] and Mac-Fadding [18] using nutrient agar and eosin methylene blue agar.

10 trained panelists were recruited to evaluate the synthesized spice for appearance, taste, aroma and overall acceptability in comparison with regular established spice bought from the market.

\section{Results and discussion}

\subsection{Proximate composition of synthesized food spice}

The proximate composition of the processed food spice is shown in Table 1 . The spice had low moisture content 14.18 $\%$ implying that the spice has low water content, dried vegetables generally has reduced water content, whereas, vegetables are known to generally have high moisture content, a factor implicated for its high perishability. Crude protein content was $11.14 \%$ which is high, protein is known to be very important and essential for the repair and 
maintenance of body cells in higher animals. The spice had low fiber (3.18\%) and high carbohydrates content (48.02 $\%)$, none starchy vegetables are the richest sources of dietary fibre, and is a veritable tool in the treatment of diabetes and obesity [19]. The ash content was low (4.31\%), implying that the spice has moderate proportions of mineral elements [20]. The percentage fat content is high $(19.17 \%)$ for a predominantly vegetable product. Dietary fats functions in the increase in foods palatability, by absorption and retention of flavours. A diet that can provide 1-2 \% calorific energy as fat is sufficient for humans, since excess fat is implicated in some cardio-vascular ailments and ageing [20]. These results reveal that this processed spice has adequate nutrients to satisfy calorie and protein demands. Further, the rich proximate composition of this traditionally processed spice can be explored in food processing, for food formulation and fortification [21].

Table 1 Proximate composition of synthesized spice

\begin{tabular}{|l|c|c|c|c|c|c|}
\hline & \multicolumn{6}{|c|}{ Parameter (\%) } \\
\cline { 2 - 7 } & Ash & Fat & Moisture & Protein & C. fibre & CHO (By diff) \\
\hline Syn. Spice & $4.31 \pm 0.86$ & $19.17 \pm 0.58$ & $14.18 \pm 0.46$ & $11.14 \pm 0.64$ & $3.18 \pm 0.88$ & 48.02 \\
\hline
\end{tabular}

\subsection{Elemental composition of synthesized food spice}

Table 2 shows the mineral elements in the food spice. The spice had appreciable amounts of minerals, especially phosphorus, potassium, sodium and calcium. The mineral content of this processed is in general higher than those reported for some other plants [22]. It has the potential to supply sufficient amount of minerals. It has high contents of $\mathrm{Ca}, \mathrm{K}, \mathrm{Mg}, \mathrm{Na}, \mathrm{P}$, Fe respectively, however, it had low $\mathrm{Zn}$ and $\mathrm{Cu}$, while $\mathrm{Hg}$ was not detected in the food spice. Phosphorus is an essential component of all cell division, reproduction and heredity. In addition Ca and P combine to prevent rickets $[20,22]$.

High $\mathrm{K} / \mathrm{Na}$ ratio in foods serves as maintenance of a correct osmotic pressure and fluid pH in the body, essential for the movement of metabolites [23]. Calcium was high (63.15 ppm). Calcium plays important roles in tissues and bones strengthening.

Olaofe et al. [21] suggested that soil composition may be a major factor influencing mineral uptake in plants. Iron content was moderately high (3.14 ppm), iron deficiency is one of the most prevalent nutritional issues in developing countries, often arising from poor bioavailability of iron in the diets [24]. This deficiency reduces work capacity and productivity in adult, increases the severity and incidence of infection, anaemia, maternal and prenatal mortality [25]. The magnesium content obtained in the spice was high (167 ppm). Magnesium helps to maintain normal nerve and muscle functions and supports a healthy immune system.

Table 2 Elemental composition of synthesized spice

\begin{tabular}{|c|c|c|c|c|c|c|c|c|c|c|}
\hline & \multicolumn{10}{|c|}{ Parameter (ppm) } \\
\cline { 2 - 12 } & $\mathbf{N a}$ & $\mathbf{C a}$ & $\mathbf{K}$ & $\mathbf{M g}$ & $\mathbf{Z n}$ & $\mathbf{F e}$ & $\mathbf{P}$ & $\mathbf{C u}$ & Hg & Vit. C \\
\hline Syn. Spice & 15.15 & 63.15 & 317 & 167 & 0.19 & 3.14 & 139.18 & 0.08 & N.D & 38.8 \\
\hline
\end{tabular}

\subsection{Anti-nutritional factors in synthesized food spice}

Table 3 presents the anti-nutritional factors of the food spice. Phytate, oxalate and tannin were found to be $8.17,0.03$ and $3.54 \mathrm{mg} / 100 \mathrm{~g}$ respectively. The presence of anti-nutritional factors in the samples is of significant importance since they are known to have some deleterious effects on both humans and other animals. Oxalate is a chelating agent, which binds calcium very effectively. Plants with high oxalate content may produce acute metabolic calcium deficiency (Hypocalcemia) when such plant products are used as a main food source [26]. One of the main health concerns about oxalate is that it can bind to minerals in the gut and prevent the body from absorbing them. The concentration of oxalate $(0.03 \mathrm{mg} / 100 \mathrm{~g})$ in the present study seems to be on the low side when compared to reported values in some plants [27].

Tannin is known to evoke growth-depressing effects in rats. In this study, the tannin level for the food spice (3.64 $\mathrm{mg} / 100 \mathrm{~g}$ ) is relatively low in comparison with tannic acid in some literatures $[27,28,29]$, the tannin content of the 
samples in this study is less than the tannin content of some dry plants (84.3 $\mathrm{mg} / 100 \mathrm{~g})$ as reported by Andualem and Gessesse [26]. The tannin content of this spice may not be as such harmful, as expected for consumption. High amount of tannins are well known to form complex with proteins and reduce the solubility of proteins, thereby making the protein less susceptible to proteolytic attack than the same proteins alone. However, relatively, some amount of tannin may have a potential role as protective factors against free radical mediated pathologies, such as cancer and atherosclerosis, in humans [30].

Table 3 Anti nutritional factors in synthesized food spice

\begin{tabular}{|c|c|c|c|}
\hline \multicolumn{4}{|c|}{ Parameter $(\mathrm{mg} / \mathbf{1 0 0}$ g) } \\
\hline Sample & Phytate & Tannin & 0xalate \\
\hline Syn. Spice & $8.17 \pm 0.88$ & $3.64 \pm 0.94$ & $0.03 \pm 0.76$ \\
\hline
\end{tabular}

\subsection{Some physico-chemical properties of synthesized food spice}

Some functional properties of the processed spice is shown in Table 4. $\mathrm{pH}$ was 6.17, tending to almost neutral pH implying that enzymes reactions are activated.

Solubility and swelling power were 6.14 and 18.17 respectively. The swelling power implies that the spice flour can swell-up to eighteen times its original volume in hot water as posited by Tester et al. [31] and may be as a function of a starch's amylopectin chain. The swelling power of the sample was higher than 2.16 reported for cassava flour [32]. Since the swelling power of the spice is high, it suggests it may find application in food production [33].

Water absorption capacity in the sample was however, moderately low 3.08. High water absorption capacity is an index of flour characterization quality for industrial purposes. The water absorption capacity of flour is a useful indicator of whether protein can be incorporated with aqueous food formulation, especially those involving dough handling [34]. The moderate water absorption capacity of the flour of this spice suggests they could be useful in soup formulations [21].

Table 4 Some functional properties of synthesized spice

\begin{tabular}{|c|c|}
\hline Parameter & Synthesized spice \\
\hline $\mathrm{pH}$ & 6.17 \\
\hline Titratable acidity & $1.37 \pm 1.24$ \\
\hline Solubility & $6.14 \pm 0.98$ \\
\hline Water absorption capacity & $3.08 \pm 1.46$ \\
\hline Swelling power (g/g) & $18.17 \pm 1.94$ \\
\hline
\end{tabular}

\subsection{Microbial assessment of synthesized food spice}

Table 5 shows some microbial properties of the synthesized spice. The total plate count is $3 \mathrm{cfu} / \mathrm{ml}$ which is considerably low, and indicates that the product is suitable for human consumption, since it is free from harmful organisms. Coliform count was nil, inferring that the product is devoid of organisms of faecal sources [35].

Table 5 Microbial properties of synthesized food spice

\begin{tabular}{|c|c|}
\hline Parameter & Synthesized spice \\
\hline Total plate count & $3 \mathrm{Cfu} / \mathrm{ml}$ \\
\hline Coliform count & $\mathrm{Nil}$ \\
\hline
\end{tabular}




\subsection{Sensory evaluation of synthesized food spice}

Table 6 shows the result of sensory evaluation of the processed spice. The synthesized spice was used in cooking fresh lean beef meat and fresh water fish. A similar spice (regular and established brand) was bought from Oja-Oba market and used in cooking the lean beef meat and fish respectively. These cooked products were then coded and evaluated by 10 trained panellists for appearance, taste and overall acceptability. There were no significant differences in the level of acceptability of all the samples. But the mean reveal that the synthesized sample was mostly accepted.

Table 6 Sensory assessment of synthesized food spice

\begin{tabular}{|c|c|c|c|c|}
\hline Sample & Appearance & Taste & Aroma & Overall acceptability \\
\hline Sample A & 6.857 & 6.571 & 6.429 & 7.143 \\
\hline Sample B & 6.286 & 6.714 & 6.857 & 7.714 \\
\hline Sample C & 6.714 & 7.000 & 7.429 & 7.286 \\
\hline Sample D & 5.714 & 7.143 & 7.429 & 6.571 \\
\hline Std er & 0.573 & 0.488 & 0.488 & 0.531 \\
\hline Sig D & NS & NS & NS & NS \\
\hline
\end{tabular}

KEY: Std er = Standard Error; Sig D = Significance Difference; NS = No Significant difference between the Sample of each Factors (appearance, taste aroma and overall acceptability) at 0.05 level of significance; Sample A= Meat Pepper soup with the synthesized spice; Sample B= Meat Pepper soup with regular spice bought from Oja Oba market, Ado Ekiti; Sample C= Fish pepper soup with the synthesized spice; Sample D= Fish pepper Soup with regular spice bought from Oja Oba market

\section{Conclusion}

From the results of the analysis, it can be inferred that the synthesized spice has a rich chemical and elemental composition in relation to some plants, particularly its crude oil and protein contents. In literature, protein is essential for growth, repair and maintenance of body cells and functions. The amount of protein in this product is high compared to that of most protein rich crops. However, it may not serve as a good source for carbohydrates compared to other food sources. Generally, plant materials are rich in cellulose, which makes them useful in diets as nutritional rhoughages. With regards to anti-nutritional studies, the anti-nutritional content of the sample under investigation is not on the high side when viewed in relation to what has been reported in some literatures, while the microbial load is very low, with no coliform organisms.

The results obtained in this study indicates a rich chemical composition for the synthesized food spice, but further studies may be needed as some species of some of the raw material used in the synthesis of the spice (particularly, Lippia multiflora) are known to contain substantial amount of a mild toxic substance, rotenone.

\section{Compliance with ethical standards}

\section{Acknowledgments}

The first and second named authors thank The Federal Polytechnic, Ado Ekiti, Ekiti State, and The Tertiary Education Trust Fund (TETFUND - IBR) Nigeria, for funding the research.

\section{Disclosure of conflict of interest}

The authors of this research work declares that there is no conflict of interests in this research.

\section{References}

[1] Abena AA, Diatewa M, Gakosso G, Gbeassor M, Ouamba JM. Analgesic, anti-pyretic \& anti-inflammatory effects of essential oils of Lippia multiflora. Fitoterapia. 2003; 74(3): 231-236.

[2] Coffi Effraim KD, Jacks TW, Sodipo OA. Histopathological studies on the toxicity of Ocimum gratissimum leave extract on some organs of rabbit. Afr. J. Biomed. 2003; 6: 21-25. 
[3] Adjanohoun E and S de Souza. Guide prathique dephytotherapie (La Sante par Lesplantes -100 plantes medicinales du Benin). Centre pilote regiona dela biodiversie africaine (CENPREBAF). 2002; 78.

[4] Akoegninou A, Van der Burg WJ, Van der Maesen LJO, Adjakidje V, Essou JP, Sinsin B, H Yedo Monhan. Flore Analytique du Benin. Backhugs. Publishers, Leiden, The Netherlands. 2006; 1034.

[5] Adjanohoun E, Ahyi MRA, Ake-Assi L, Elewude JA, Dramane K, Fadoju SO, Gbile ZO, Goudole E, Johnson CLA, Keita A, Morakinyo 0, Ojewole JAO, Olatunji AO, Sofowora EA. Traditional medicine and pharmacopoeia. Contribution to ethnobotanical floristic studies in Western Nigeria. Nigeria: Pub. Organization of African Unity, Scientific Technical and Research Commission. Lagos. 1991; 420.

[6] Kunle 0, Okogun J, Egamana E, Emojerwe E, Shok M. Antimicrobial activity of various extracts and carvacrol from lippie multiflora leaf extract. Phytomedicine. 2003; 10: 59-61.

[7] Pascual ME, Slowing K, Caretero E, Sanchez DM, villar A. Lippia: Traditional uses, chemistry and pharmacology; review. Journal Ethnopharmacology. 2001; 76: 201-214.

[8] Ettou-Ossibi AW, Dimo T, Elion-Itou RDG, Nsinde-Ntandon GF, Nzonzi J, Bilanda DC, Ouamba JM, AA Abena. Effect de l'extract aqueous de lippie multiflora Moldenke Sur' hypertension arte rielle induite par le DOCA-sel chez le rat. Phyto theraple. 2012; 10(6): 363-368.

[9] Badreldin HA, Gerald B, Musbah OT, Abderrahim N. Some phytochemical, pharmacological and toxicological properties of Zingiber officinale Roscoe. A review of recent research. Food and Chemical Toxicology. 2008; 46(2): 409-420.

[10] Srinivasan K. Black pepper and its pungent principle- piperine: A review of diverse physiological effects. Critical reviews in food science and nutrition. 2007; 47(8): 735-748.

[11] Aguiyi CK, BEH Sawaliho, S Kone, G Koukoua, YT N'Guessan. Étude des proprieties physico-chimiques des huiles essentielles de Lippia multiflora, Cymbopogon citratus, Cybopogon nardus, Cymbopogon giganteus. C. R. Chemie. 2004; 7: 1039-1042.

[12] AOAC. Association of Official Analytical Chemist. International 18 ${ }^{\text {th }}$ Edition. Gathersburg, MD USA. Official methods. 2005.

[13] Ani AI, Ochigbo SS, Jacob JO, N'aamitso MM, Abubakar U.Proximate and mineral composition of different species of kolanuts. European, Journal of Applied Engineering and Scientific Research. 2012; 1(3): 44-47.

[14] Oladele AK and Aina JO. Chemical composition and functional properties of flour from two varieties of tigernut (Cyperus esculentus). African journal of biotechnology. 2007; 6(21): 2413-2476.

[15] Harbone J.B: Phytochemical method; A Guide to modern techniques of plant Analysis, $1^{\text {st }}$ Edition, Chapman and Hall London. 1990; 288.

[16] Pearson D. The Chemical Analysis of Foods ( $7^{\text {th }}$ Ed.), Longman Group Ltd, London.1993.

[17] Adegoke GO. Understanding food microbiology, Shalom prints, Ibadan, Nigeria. 2000.

[18] MacFadding JF. Biochemical tests for identification of medical bacterial, $3^{\text {rd }}$ edition, lippinott William and Wilkins, Philadelphia, PA. 2000; 1: 912.

[19] Saldanha LG. Fiber in the diets of U.S Children. Results of National Survey.Pediat. 1995; 96: 994-996.

[20] Antia BS, EJ Akpan, PA Okon, LU Umoren. Nutritive and anti-nutritiv properties of sweet potatoes (Ipomoea batatas) leaves. Pak. J. of Nutr. 2006; 5: 166-167.

[21] Olaofe 0, Adeyemi FO, Adediran GO. Amino acid, mineral and functional properties of some oil seeds. J. of agric. and food chem. 1987; 42: 878-881.

[22] Akinhanmi TF, Atasie VN, Akintokun PO. Chemical Composition and Physicochemical Properties of Cashew nut (Anacardium occidentale) Oil and Cashew nut Shell Liquid. J Agri Food Enviro Sci. 2008; 2 (1): ISSN 1934-7235.

[23] Lake B, waterworth M. Food and Nutrition. Mill and Boon Ltd, London. 1980; 405.

[24] WHO-UNICEF. Indicators and strategies for iron Deficiency and Anaemia programs. World Health Organization Technical Report Series, WHO - UNICEF, New York. 1993.

[25] Scrimshaw NS. Iron Deficiency. Sci. Am. 1991; 265: 46-52. 
[26] Andualem B, Gessesse A. Proximate composition, mineral content and anti-nutritional factors of Brebra (Millettia ferruginea) seed flour as well as physicochemical characterization of its seed oil. Springer Plus. 2014; 3: 298.

[27] Umoren UE, Essien AI, Ukorebi BA, Essien EB. Chemical evaluation of the seeds of Milletia obanensis. Food Chem. 2005; 91: 195-201.

[28] Akinyede AI, Amoo IA, Eleyinmi AF. Chemical and functional properties of full fat and defatted Dioclea reflexa seed flours. J. Food Agri Envir. 2005; 3(2): 112-115.

[29] Enujiugha VN. Chemical and functional characteristics of conophor. Pak. J. Nutr. 2003; 2(6): 335-338.

[30] Hangen L, Bennin MR. Consumption of black beans and navy beans (Phaseolus vulgaris) reduced azoxymethaneinduced colon cancer in rats. Nutr Canc. 2002; 44: 60-65.

[31] Tester RF, K Arkalas J. Swelling and Gelatinization of oat starches. Cereal Chem. 1990; 98: 271-273.

[32] Okezie BO, Bello AB. Physiochemical and function properties of winged bean flours and isolate compared with Soy isolate. J. food Sci. 1998; 53(2): 445-450.

[33] Mc comick KM, Panozzo JF, Hong SH. A swelling power test for selecting potential noodle quality wheats. Austrialian Journal of Agricultural Research. 1991; 42(31): 317-323.

[34] Osungbaro TO, Jimoh D, Osundiyi E. Functional and pasting properties of composite cassava-sorghum flour meals. Agriculture and Biology Journal of North America. 2010; 1(4): 715-720.

[35] Satcheu FB, VR Bruce, G Allen, WH Andrews, HR, Crerber. Microbiological survey of selected imported spices and associated faecal pellet specimens. Journal Association Office. Analytical Chemistry. 1989; 72: 632-637. 